\title{
Effects of catnip (Nepeta cataria L.) and Mexican sunflower (Tithonia diversifolia L.) density on growth, yield, and proximate composition of jute mallow (Corchorus olitorius L.)
}

\author{
0. P. Ayodele', 0. A. Aluko², 0. D. Adegbaju \\ ${ }^{1}$ Department of Agronomy, Adekunle Ajasin University Akungba-Akoko, Ondo State, Nigeria, e-mail: olatunde.ayodele@aaua.edu.ng \\ ${ }^{2}$ Institute of Agricultural Research and Training, Obafemi Awolowo University, Moor Plantation, P. M. B 5029, Ibadan, Nigeria, \\ e-mail: bunmialuko2010@gmail.com \\ ${ }^{3}$ Medicinal Plants and Economic Development (MPED) Research Centre, Department of Botany, University of Fort Hare, Alice \\ 5700, Eastern Cape Province, South Africa, e-mail: oadegbaju@ufh.ac.za
}

Purpose. Jute mallow (Corchorus olitorius L.) is a mucilaginous vegetable and fiber crop cultivated in the tropics, where catnip (Nepeta cataria L.) and Mexican sunflower (Tithonia diversifolia L.) are common weeds. Hence, the study investigated the growth, yield, and nutrient level of jute mallow in weed-free, catnip, and Mexican sunflower environments. Methods. The study involved two screen-house experiments in a Completely Randomized Design (CRD) with six replications. The treatments were 0 (control), 2, 4, 6, 8, and 10 weed plants per pot in both experiments. These are 0, 100, 200, 300, 400, and 500 weed count per square meter equivalent, based on the surface area of the pots used. Mexican sunflower and catnip plants interacted with jute plants in the first and second experiments, respectively. Growth parameters of jute mallow were recorded weekly from 5 to 8 weeks after sowing (WAS), and harvesting was done at 8 WAS. The proximate composition of jute was evaluated using standard procedures outlined by AOAC. The data collected were subjected to analysis of variance (ANOVA), and means were separated using Duncan Multiple Range Test (DMRT) at $P<0.05$. Results. Catnip and Mexican sunflower negatively impacted the morphological features of jute mallow from 100 plants per square meter upwards. Catnip and Mexican sunflower, at 300 and $100-500$ plants per square meter, respectively, reduced the dry weight of jute mallow. The crude protein content of jute mallow was also lessened by Mexican sunflower at some point. Conclusions. The study recommends that the density of catnip and Mexican sunflower plants interacting with jute mallow should be maintained below 100 plants per square meter to prevent yield loss.

Keywords: Corchorus olitorius; Mexican sunflower; catnip; weed density; proximate composition.

\section{Introduction}

People consume vegetables to overcome nutritional problems. Therefore, the proximate composition of a vegetable crop is vital. Jute mallow (Corchorus olitorius L.) is an annual herb in the Malvaceae family [1] that is rich in protein, carbohydrates, minerals, and vitamins $[2,3]$. It is a popular mucilaginous vegetable cultivated in many parts of the world [4]. Nursing mothers use soup made from jute mallow to introduce solid foods to babies after weaning in southwestern Nigeria [5]. Besides the nutritional importance, the plant's bast fiber is a raw material used for textile production [6]. The plant may reach $2.4 \mathrm{~m}$ in height with few or no branches, and the leaves are simple, lanceolate, finely serrated, and alternate (Fig. 1a).

\section{O. P. Ayodele}

https://orcid.org/0000-0001-7348-7954

o. A. Aluko

https://orcid.org/0000-0003-2896-9668

O. D. Adegbaju

https://orcid.org/0000-0002-7557-6608
Previous studies showed that weeds are major constraints in jute production [7-9]. Weeds such as Cyperus rotundus L., Echinochloa colonum (L.) Link. and Digitaria sanguinalis (L.) Scop. have been reported to reduce jute mallow's yield (Hossain et al., 2020). However, contrary to weeds' general attributes, some weeds positively influence crop growth [11]. These two seemingly opposite attributes, the detrimental and the beneficial aspects of weeds, can be reconciled based on weed species and densities.

Generally, a negative correlation exists between weed density and crop growth [7]. Also, Ronchi \& Silva [12] reported that weeds' influence on crop growth varies in intensity depending on the species involved. Therefore, the impact of weed species at various densities should be a rational premise for weed management decisions. Unfortunately, in many parts of the world, the action threshold for weed control is fixed by farmers without empirical references. For this reason, weed management decisions are sometimes untimely and ineffective.

The beneficial economic importance of some weeds may influence the consideration to suppress their population, particularly in the ab- 
sence of empirical reference. In the tropics where jute mallow plants are cultivated, catnip (Nepeta cataria L.) and Mexican sunflower (Tithonia diversifolia L.) are common weeds with some positive attributes [13, 14]. Catnip, a perennial herbaceous plant of the mint family Lamiaceae (15; Fig. 1b), repels insects [13]. The bioherbicidal potential of its extract has also been reported in many studies [14-16]. However, there is a paucity of information on its in-situ interactions with other plants. Mexican sunflower, an annual plant from the Asteraceae family, improves soil fertility [13] and controls nematodes [17, Fig. 1c].
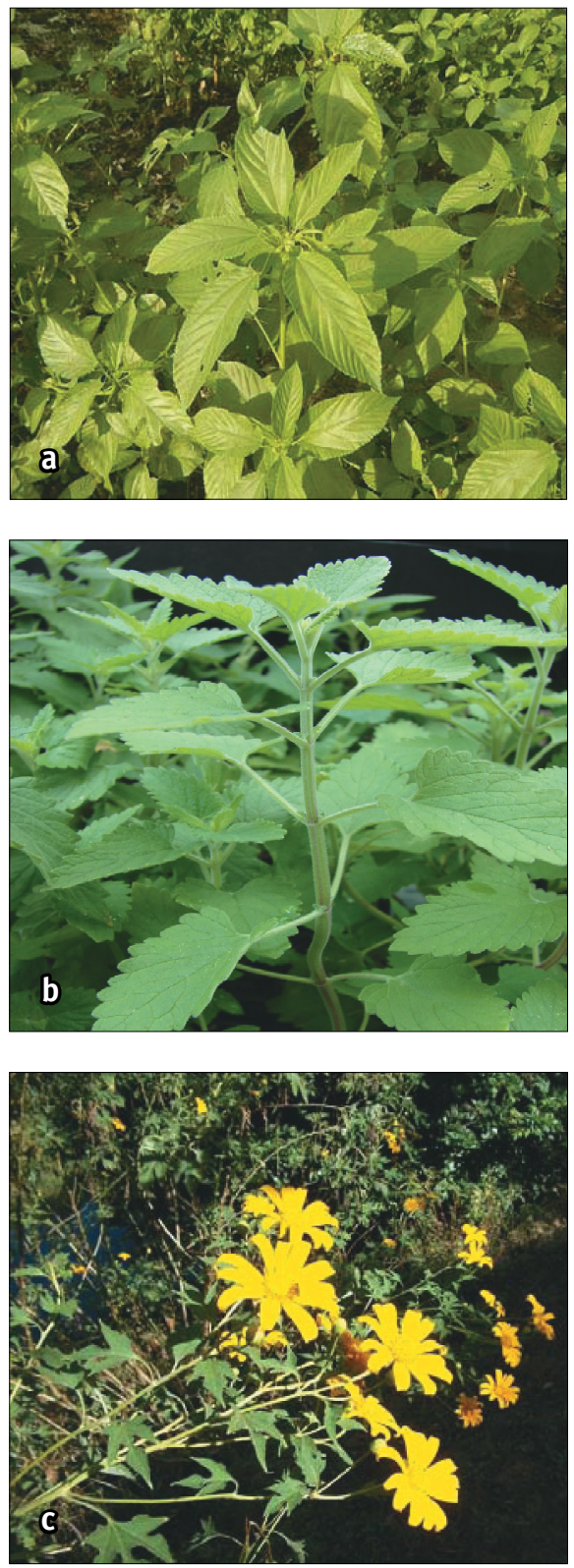

Fig. 1. Picture of jute plants (Fig. 1a), catnip plants (Fig. 1b), and Mexican sunflower plants (Fig. 1c)

The pest attributes of catnip and Mexican sunflower qualify them as weeds. Bozok et al. [18] reported that secondary metabolites from catnip had a negative effect on the growth of wheat (Triticum aestivum L.). Also, Olabode et al. [19] found that Mexican sunflower reduced the yield of water yam (Dioscorea alata L.) to 3 tons per hectare against 21 tons per hectare in plastic mulch plots. Hence, this study sought to investigate the effects of catnip and Mexican sunflower on the growth, yield, and nutrient composition of jute mallow at varying densities.

\section{Materials and methods}

\section{Experimental site}

This study was conducted in a screen-house at Adekunle Ajasin University Akungba Akoko, Nigeria $\left(7^{\circ} 37^{\prime} \mathrm{N}, 5^{\circ} 44^{\prime} \mathrm{E}\right)$. Prior to the screenhouse experiments, seedlings were raised in a nursery close to the screen-house. The temperature and relative humidity in the screenhouse during the trial were within the range of $22-35{ }^{\circ} \mathrm{C}$ and $51-77 \%$, respectively.

\section{Collection of materials}

The study involved the collection of Mexican sunflower and catnip seeds from Adekunle Ajasin University Teaching and Research Farm, Akungba-Akoko, and jute seeds from Ondo State Agricultural Development Programme (ADP) Ikare-Akoko. The seeds were shortly stored in paper bags in a dry environment. Topsoil, 0$15 \mathrm{~cm}$, from fallowing arable farmland in Adekunle Ajasin University Teaching and Research Farm, Akungba-Akoko, was collected using a shovel.

The physicochemical properties of the soil were determined using standard methods and are presented in Table 1 . Soil organic carbon was evaluated using the dichromate wet oxidation method. The organic matter was obtained by multiplying the organic carbon by 1.724 . The total nitrogen was determined by micro-Kjeldahl digestion and distillation techniques. Soil available phosphorus was extracted using Bray-1 solution and determined by molybdenum blue colorimetry. Exchangeable acidity, potassium, calcium, and magnesium were extracted using $1 \mathrm{~N}$ ammonium acetate. Thereafter, potassium was determined using a flame photometer (Jenway, PFP 7/C, England). Ethylenediaminetetraacetic acid (EDTA) titration method was used to determine calcium and magnesium. The soil $\mathrm{pH}$ was determined at a soil to water ratio of $1: 2$ using a digital electronic $\mathrm{pH}$ meter (Mettler Toledo, FE20, Switzerland).

The soil was sieved into nylon bags, kept wellwatered, and solarized for two weeks to deplete the weeds' seed bank. After this, seventy-two (72) nylon pots measuring $22 \times 16 \mathrm{~cm}$ and $200 \mathrm{~cm}^{2}$ at the open end were filled with $10 \mathrm{~kg}$ soil each and later arranged $1 \mathrm{~m}$ apart in the screen-house. 
Raising of seedlings in the nursery

Three beds of $1 \times 1 \mathrm{~m}$ were made to raise the seeds of jute, Mexican sunflower, and catnip separately. Shades were made on these beds with thatch to reduce sunlight intensity. Daily watering of the beds went on for the two weeks that the seedlings stayed in the nursery.

Transplanting of jute and weed species

Direct sowing of jute and weed into the same pot may not guarantee uniformity among the experimental units due to seed dormancy. Hence, the transplanting of jute and weed seedlings into the same pot was considered appropriate. Seedlings of jute, Mexican sunflower, and catnip were carefully uprooted and transplanted from the beds to the pots at two weeks after sowing (WAS). This activity was carried out in the evening to lessen water loss through transpiration. Jute seedlings were transplanted at the rate of one plant per pot. However, Mexican sunflower and catnip were transplanted into different pots according to the treatment plan (Fig. 2).

\section{Experimental design and treatments}

The screen-house phase of this study comprised two experiments running concurrently. In October 2019, the experiments were laid out in a completely randomized design with six replications. The first and second experiments had varying densities of Mexican sunflower and catnip as treatments, respectively. Also, weed-free treatment was incorporated as the control treatment in both experiments. The experimental treatments were $0,2,4,6,8$, and 10 weed plants per pot coexisting with a jute plant. These are equivalent to $0,100,200,300$, 400 , and 500 weed plants per square meter based on the surface area of the pots used.

\section{Collection of data}

After three weeks of jute and weed interaction, growth parameters of jute plants, such as the plant height, number of branches, and number of leaves, were evaluated and recorded weekly, from 5 to 8 WAS. The jute plants were uprooted at 8 WAS when the shoots were succulent, and the fresh weights were recorded. Samples were taken from the freshly harvested jute plants and were subjected to proximate analysis to evaluate their nutrient composition. After oven drying the fresh jute plants samples at $80{ }^{\circ} \mathrm{C}$ for 48 hours, the dry weights were measured using an electronic balance (WANT, WT5002K, China).

\section{Proximate analysis}

Jute plants from each treatment were analyzed for moisture, ash, lipid, dietary fiber, protein, and carbohydrate following standard procedures outlined by the Association of Official Analytical Chemists [20]. The moisture content was determined by drying jute samples to a constant weight in an air-oven (Unident, UNI0009B, India) at $105{ }^{\circ} \mathrm{C}$. The study employed the Soxhlet extraction method to evaluate the lipid content. Defatted samples were digested with $0.26 \mathrm{~N}$ sulphuric acid and $0.23 \mathrm{~N}$ potassium hydroxide solutions to determine the dietary fiber content. The total amount of nitrogen was determined using the micro-Kjeldahl method, and its protein content was estimated using a multiplying factor of 6.25.

Treatment 3

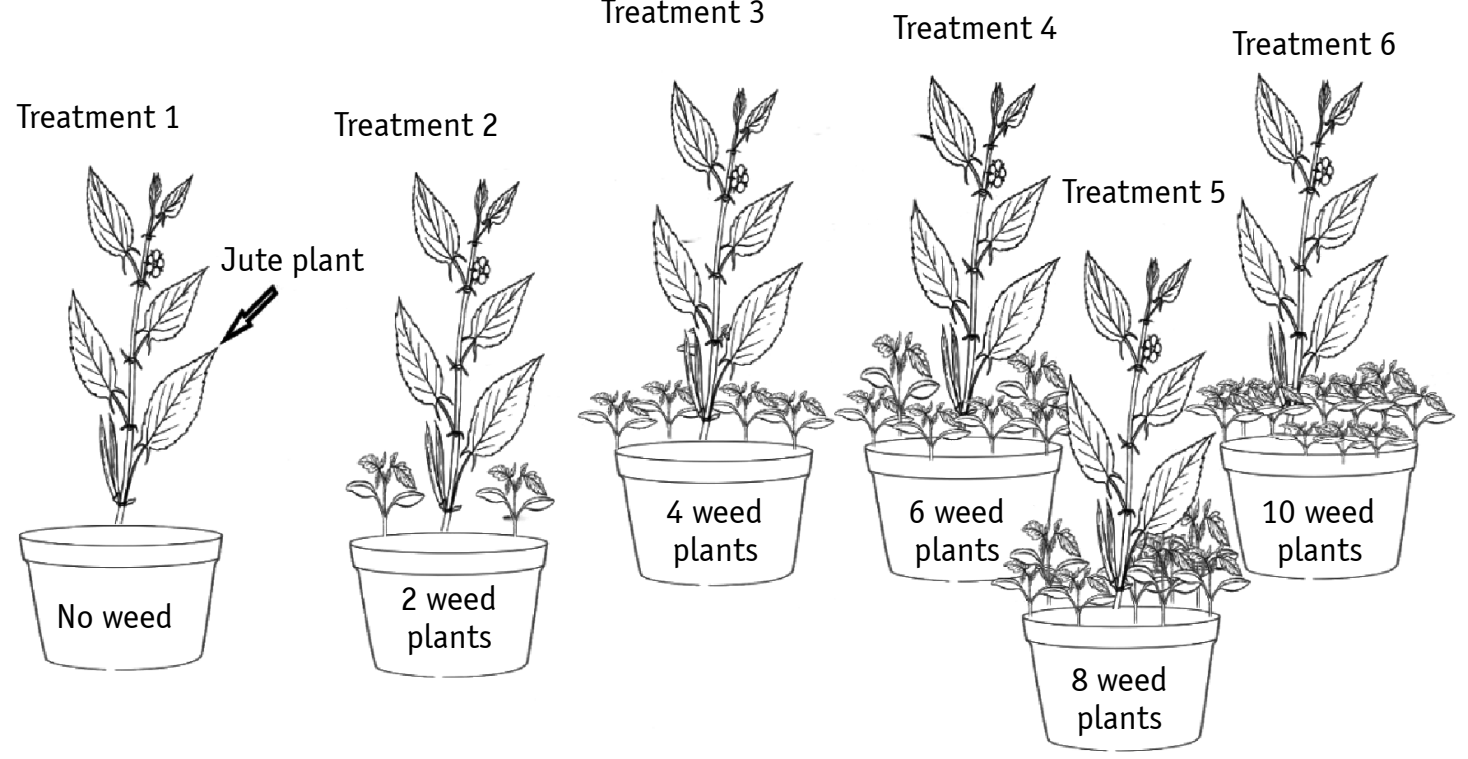

Fig. 2. Treatment plan showing the varying density of weeds coexisting with jute plant 
The ash content was evaluated by subjecting the samples to the heat of $600{ }^{\circ} \mathrm{C}$ for 5 hours in a muffle furnace (BIOBASE, MX6-10T/TP, China). Finally, the carbohydrate content was calculated by subtracting the crude protein, crude fiber, ash, and lipid from the total dry matter.

\section{Data analysis}

Data on jute growth and proximate composition were subjected to analysis of variance (ANOVA) and post-hoc analysis using IBM SPSS Statistics 23 software [21]. The treatment means were separated using the Duncan Multiple Range Test (DMRT) at 5\% probability level.

\section{Results}

Effects of Mexican sunflower density on the growth of jute

The density of the Mexican sunflower plant had a significant $(P<0.05)$ effect on the number of jute leaves at 5 to 8 WAS (Table 2). Notably, at 6 weed plants per pot, Mexican sunflower interacting with jute plants resulted in a significantly reduced number of jute leaves at 5 to 8 WAS. In contrast, at 2 weed plants per pot, there was no significant reduction in the number of leaves on jute plants interacting with Mexican sunflower at 5 to 8 WAS. However, Mexican sunflower density greater than 2 plants per pot resulted in a significantly reduced number of jute leaves at 8 WAS.

The densities of Mexican sunflower evaluated in this study significantly affected the number of jute branches at 6 to 8 WAS (Table 2). At 6 and 8 weed plants per pot, Mexican sunflower interacting with jute plant resulted in a significantly reduced number of jute branches at 6 to 8 WAS. In contrast, 2 Mexican sunflower plants per pot and weed-free control resulted in a comparable number of jute branches at 6 to 8 WAS. However, Mexican sunflower greater than 2 plants per pot resulted in a significantly reduced number of jute branches at 8 WAS.

The densities of Mexican sunflower evaluated in this study did not significantly $(P<0.05)$ reduce the height of jute plant at 5 and 6 WAS. In contrast, a significant reduction in the height of jute plant was observed from the interactions involving Mexican sunflower density greater than 2 plants per pot at 7 WAS and all densities at 8 WAS.

Effect of Mexican sunflower density on the yield of jute

Mexican sunflower density did not significantly $(P<0.05)$ reduce the fresh weight of jute plant at 8 WAS (Table 3). However, the total dry weight of jute plant was significantly reduced by $42-77 \%$ at 8 WAS compared to the weed-free control. Among the Mexican sunflower and jute plant interactions, the highest dry weight of jute plant resulted from 4 weed plants per pot and it was comparable to 2 weed plants per pot. Also, interaction involving high Mexican sunflower density such as 10 weed plants per pot significantly reduced the dry weight of jute than those involving low densities such as 2 and 4 weed plants per pot.

Effect of Mexican sunflower density on the nutritional quality of jute

Mexican sunflower density had no significant effect on the moisture, ash, crude fiber,

Physicochemical properties of the potting soil

Table 1

\begin{tabular}{|c|c|c|c|c|c|c|c|c|c|c|c|c|c|c|}
\hline OC & $O M$ & $\mathrm{~N}$ & $\mathrm{P}$ & $\mathrm{K}$ & $\mathrm{Na}$ & $\mathrm{Ca}$ & $\mathrm{Mg}$ & $\mathrm{EH}^{+}$ & $\mathrm{EAl}^{3+}$ & $\mathrm{CEC}$ & $\mathrm{pH}$ & Sand & Clay & Slit \\
\hline \multicolumn{8}{|c|}{$(\%)$} & & $\mathrm{mg} / \mathrm{kg}$ & \multicolumn{8}{|c|}{$(\mathrm{Cmol} / \mathrm{kg})$} & & $(1: 2) \mathrm{H}_{2} \mathrm{O}$ & & $(\%)$ \\
\hline 0.54 & 0.9 & 0.12 & 12.2 & 0.14 & 0.11 & 1.2 & 0.9 & 1.1 & 0.01 & 14.12 & 5.24 & 57 & 28 & 15 \\
\hline
\end{tabular}

*OC: organic carbon, $\mathrm{OM}$ : organic matter, $\mathrm{EH}^{+}$: exchangeable hydrogen, $\mathrm{EAL}^{3+}$ : exchangeable aluminium, and $\mathrm{CEC}$ : cation exchange capacity

Effect of Mexican sunflower density on the number of leaves, number of branches, and plant height of jute

\begin{tabular}{|c|c|c|c|c|c|c|c|c|c|c|c|c|}
\hline \multirow{2}{*}{ Sunflower - Jute } & \multicolumn{4}{|c|}{ No of leaves (count/plant) } & \multicolumn{4}{|c|}{ No of branches (count/plant) } & \multicolumn{4}{|c|}{ Plant height $(\mathrm{cm})$} \\
\hline & \multicolumn{4}{|c|}{ WAS } & \multicolumn{4}{|c|}{ WAS } & \multicolumn{4}{|c|}{ WAS } \\
\hline (Sunflower plants/pot) & 5 & 6 & 7 & 8 & 5 & 6 & 7 & 8 & 5 & 6 & 7 & 8 \\
\hline 2 & $5.67 a b$ & $19.67 a$ & $28.00 \mathrm{a}$ & $34.00 \mathrm{ab}$ & $0 a$ & $6.33 a b$ & 10.50ab & 13.00ab & $6.17 a b$ & $14.33 a$ & $26.5 a b$ & $33.5 b$ \\
\hline 4 & $5.50 \mathrm{ab}$ & 15.83ab & 24.33ab & $26.33 \mathrm{bc}$ & $0 a$ & $6.17 a b$ & $9.50 \mathrm{ab}$ & 11.17bc & $5.33 b$ & $13.67 a$ & $22.33 b$ & $26.83 b$ \\
\hline 6 & $4.83 \mathrm{~b}$ & $11.17 \mathrm{~b}$ & $14.67 b$ & $18.00 \mathrm{c}$ & $0 \mathrm{a}$ & $5.00 \mathrm{~b}$ & $8.33 b$ & $9.33 c$ & $6.83 a b$ & $13.33 a$ & $20.5 b$ & $24.33 b$ \\
\hline 8 & $5.67 a b$ & $12.00 \mathrm{~b}$ & $14.83 b$ & $21.67 c$ & Oa & $4.83 b$ & $8.17 b$ & $9.50 c$ & $8.17 a$ & $14.17 a$ & $20.67 b$ & $24.00 \mathrm{~b}$ \\
\hline 10 & $5.83 a b$ & $11.83 b$ & 21.33ab & $24.67 \mathrm{bc}$ & Oa & $6.33 a b$ & 9.33ab & $10.50 \mathrm{bc}$ & $8.17 a$ & $13.83 a$ & $22.17 \mathrm{~b}$ & $25.33 b$ \\
\hline Control & $6.33 a$ & $22.67 a$ & $30.67 a$ & $40.83 a$ & $0 \mathrm{a}$ & $7.67 a$ & $10.83 a$ & $14.33 a$ & 7.17ab & $18.17 \mathrm{a}$ & $32.83 a$ & 43.17a \\
\hline
\end{tabular}

*Sunflower - Jute: Mexican sunflower - Jute Interaction, WAS: weeks after sowing.

Means in a column followed by the same letter are not significantly different according to DMRT $(P=0.05)$ 
Table 3

Effect of Mexican sunflower density on the weights of jute at 8 weeks after sowing

\begin{tabular}{|c|c|c|}
\hline$\frac{\text { Mexican sunflower - Jute Interaction }}{\text { (Sunflower plants/pot) }}$ & $\begin{array}{l}\text { Total fresh } \\
\text { weight }(\mathrm{g})\end{array}$ & $\begin{array}{c}\text { Total dry } \\
\text { weight }(\mathrm{g})\end{array}$ \\
\hline 2 & $6.57 a$ & $2.21 b c$ \\
\hline 4 & $4.67 a$ & $2.67 b$ \\
\hline 6 & $2.20 a$ & $1.38 \mathrm{~cd}$ \\
\hline 8 & $5.57 a$ & $1.66 \mathrm{~cd}$ \\
\hline 10 & $3.90 a$ & $1.06 \mathrm{~d}$ \\
\hline Control & $9.20 \mathrm{a}$ & $4.64 a$ \\
\hline
\end{tabular}

Means in a column followed by the same letter are not significantly different according to DMRT $(P=0.05)$

and fat content of the jute plant (Table 4). Conversely, the crude protein content of jute was significantly reduced by $32 \%$ at a Mexican sunflower density of 6 plants per pot. However, other Mexican sunflower densities and weedfree control had jute plants with comparable crude protein. The carbohydrate content of jute increased significantly $(P<0.05)$ by $46 \%$ at the Mexican sunflower density of 6 plants per pot. Nevertheless, other Mexican sunflower densities and weed-free control had jute plants with comparable carbohydrate content. jute

Effect of catnip density on the growth of

The density of catnip had a significant $(P<0.05)$ effect on the number of jute leaves at 5 to 8 WAS (Table 5). The catnip densities evaluated in this study significantly reduced the number of jute leaves from 6 to 8 WAS compared to the weed-free control. Consistently, at 6 to 8 WAS, a catnip density of 10 plants per pot resulted in fewer jute leaves than 2 and 4 catnip plants per pot.

Catnip density also had a significant $(P<0.05)$ effect on the number of jute branches at 6 to 8 WAS (Table 5). All the densities of catnip evaluated significantly reduced the number of jute branches at 8 WAS. However, the reduction in jute branches manifested earlier in high catnip densities. Hence, the number of jute branches in catnip densities of 2,6 , and 10 plants per pot reduced for 1,2 , and 3 weeks, respectively. The lowest number of jute branches was consistently recorded in a catnip density of 10 plants per pot.

The density of catnip weed had a significant $(P<0.05)$ effect on the height of the jute plant at 5 to 8 WAS compared to the weed-fee control (Table 5). The catnip densities evaluated in this study significantly reduced the height of jute plants at 6 to 8 WAS. Jute plants that interacted with catnip densities reduced by $32-55 \%$ in height at 8 WAS compared to the weed-free control. Noticeably, the height of jute plants that interacted with 10 catnip plants per pot was significantly lesser than those of 2 and 4 catnip plants per pot at 8 WAS.

Effect of Mexican sunflower density on the nutritional composition of jute at 8 weeks after sowing

\begin{tabular}{|c|c|c|c|c|c|c|}
\hline \multirow{2}{*}{$\begin{array}{c}\text { Mexican sunflower } \\
\text { Jute Interaction }\end{array}$} & \multicolumn{7}{|c|}{ Jute } \\
\cline { 2 - 7 } & Moisture & Ash & Crude Protein & Crude Fiber & Fat & CH0 \\
\hline (Sunflower plants/pot) & $(\%)$ & $(\%)$ & $(\%)$ & $(\%)$ & $(\%)$ & $(\%)$ \\
\hline 2 & $20.79 \mathrm{a}$ & $14.30 \mathrm{a}$ & $13.34 \mathrm{ab}$ & $18.61 \mathrm{a}$ & $10.41 \mathrm{a}$ & $22.57 \mathrm{~b}$ \\
4 & $16.06 \mathrm{a}$ & $12.34 \mathrm{a}$ & $12.00 \mathrm{ab}$ & $24.23 \mathrm{a}$ & $10.60 \mathrm{a}$ & $24.77 \mathrm{ab}$ \\
6 & $17.98 \mathrm{a}$ & $13.22 \mathrm{a}$ & $11.51 \mathrm{~b}$ & $17.06 \mathrm{a}$ & $10.40 \mathrm{a}$ & $29.84 \mathrm{a}$ \\
8 & $19.92 \mathrm{a}$ & $12.02 \mathrm{a}$ & $15.37 \mathrm{ab}$ & $15.94 \mathrm{a}$ & $10.34 \mathrm{a}$ & $26.41 \mathrm{ab}$ \\
10 & $20.95 \mathrm{a}$ & $12.75 \mathrm{a}$ & $14.29 \mathrm{ab}$ & $19.09 \mathrm{a}$ & $11.23 \mathrm{a}$ & $21.69 \mathrm{~b}$ \\
Control & $20.96 \mathrm{a}$ & $13.80 \mathrm{a}$ & $16.97 \mathrm{a}$ & $17.62 \mathrm{a}$ & $10.14 \mathrm{a}$ & $20.50 \mathrm{~b}$ \\
\hline
\end{tabular}

Means in a column followed by the same letter are not significantly different according to DMRT $(P=0.05)$

Effect of catnip density on the number of leaves, number of branches, and plant height of jute

Table 5

\begin{tabular}{|c|c|c|c|c|c|c|c|c|c|c|c|c|}
\hline \multirow{3}{*}{$\begin{array}{c}\text { Catnip - } \\
\text { Jute Interaction } \\
\begin{array}{c}\text { (Catnip } \\
\text { plants/pot) }\end{array}\end{array}$} & \multicolumn{4}{|c|}{ No of leaves (count/plant) } & \multicolumn{4}{|c|}{ No of branches (count/plant) } & \multicolumn{4}{|c|}{ Plant height $(\mathrm{cm})$} \\
\hline & \multicolumn{4}{|c|}{ WAS } & \multicolumn{4}{|c|}{ WAS } & \multicolumn{4}{|c|}{ WAS } \\
\hline & 5 & 6 & 7 & 8 & 5 & 6 & 7 & 8 & 5 & 6 & 7 & 8 \\
\hline 2 & $4.50 \mathrm{~b}$ & $20.83 b$ & $26.5 b c$ & $37.17 b$ & $0 \mathrm{a}$ & $8.17 a b$ & $9.83 a-c$ & $12.5 b$ & $5.33 b$ & $14.33 b$ & $24.17 b$ & $34.33 b$ \\
\hline 4 & $6.17 a$ & $21.17 b$ & $28.00 \mathrm{~b}$ & $39.17 b$ & $0.17 a$ & $9.17 \mathrm{a}$ & 10.67ab & $12.33 b$ & $5.00 \mathrm{~b}$ & $14.00 \mathrm{~b}$ & $24.50 \mathrm{~b}$ & $34.50 \mathrm{~b}$ \\
\hline 6 & 5.83ab & $13.83 b c$ & $15.83 \mathrm{~cd}$ & $24.67 b c$ & $0 a$ & $6.67 a b$ & $8.00 b c$ & $10.17 b c$ & $6.33 a b$ & $13.00 \mathrm{~b}$ & $21.83 b$ & $27.17 b c$ \\
\hline 8 & $5.33 a b$ & $13.83 b c$ & $20.33 b-d$ & $28.00 b c$ & $0.17 a$ & 7.00ab & $8.17 b c$ & $10.67 b c$ & $5.17 b$ & $12.33 b$ & $20.17 b$ & $29.17 b c$ \\
\hline 10 & $5.33 a b$ & $11.00 \mathrm{c}$ & $13.33 d$ & $17.50 c$ & $0 a$ & $5.00 \mathrm{~b}$ & $6.67 c$ & $8.67 c$ & $6.33 a b$ & $11.67 b$ & $18.33 b$ & $23.00 \mathrm{c}$ \\
\hline Control & $6.17 a$ & $31.83 a$ & $43.00 a$ & $58.33 a$ & $0.5 a$ & $10.33 a$ & $13.00 \mathrm{a}$ & $15.83 a$ & $7.67 a$ & $21.00 \mathrm{a}$ & $32.83 a$ & $50.83 a$ \\
\hline
\end{tabular}

*WAS: weeks after sowing.

Means in a column followed by the same letter are not significantly different according to DMRT $(P=0.05)$ 
Effect of catnip density on the yield of jute

The density of catnip significantly $(P<0.05)$ reduced the total fresh weight of jute by 50$90 \%$ at 8 WAS compared to weed-free control (Table 6). In addition, the fresh weights of jute plants that interacted with catnip at 2 and 4 plants per pot were significantly higher than those of 10 plants per pot, which had the least. Similarly, at 6 weed plants per pot, catnip significantly reduced the dry weight of jute by $64 \%$ at 8 WAS. However, other catnip densities and weed-free control resulted in comparable dry weights of jute plants.

Effect of catnip density on the weights of jute at 8 weeks after sowing

\begin{tabular}{|c|c|c|}
\hline $\begin{array}{c}\text { Catnip - Jute } \\
\text { Interaction }\end{array}$ & $\begin{array}{c}\text { Total fresh weight } \\
\text { (g/plant) }\end{array}$ & $\begin{array}{c}\text { Total dry weight } \\
\text { (g/plant) }\end{array}$ \\
\cline { 1 - 2 } (Catnip plants/pot) & $7.17 \mathrm{bc}$ & $2.33 \mathrm{ab}$ \\
\cline { 1 - 2 } 2 & $9.03 \mathrm{~b}$ & $1.79 \mathrm{ab}$ \\
6 & $3.37 \mathrm{~d}$ & $1.04 \mathrm{~b}$ \\
8 & $4.53 \mathrm{~cd}$ & $1.87 \mathrm{ab}$ \\
10 & $1.77 \mathrm{~d}$ & $1.62 \mathrm{ab}$ \\
Control & $18.17 \mathrm{a}$ & $2.86 \mathrm{a}$ \\
\hline
\end{tabular}

Means in a column followed by the same letter are not significantly different according to DMRT $(P=0.05)$

Effect of catnip density on the nutritional quality of jute

The density of catnip weed did not have a significant $(P<0.05)$ effect on the moisture, ash, crude protein, crude fiber, fat, and carbohydrate contents of jute at 8 WAS (Table 7).

Table 7

Effect of catnip density on the nutritional composition of jute at 8 weeks after sowing

\begin{tabular}{|c|c|c|c|c|c|c|}
\hline $\begin{array}{c}\text { Catnip - } \\
\text { Jute } \\
\text { Interaction }\end{array}$ & \multicolumn{7}{|c|}{ Jute } \\
\hline $\begin{array}{c}\text { (Catnip } \\
\text { plants/pot) }\end{array}$ & Moisture & Ash & $\begin{array}{c}\text { Crude } \\
\text { protein }\end{array}$ & $\begin{array}{c}\text { Crude } \\
\text { fiber }\end{array}$ & Fat & CHO \\
\hline 2 & $15.44 \mathrm{a}$ & $14.2 \mathrm{a}$ & $14.29 \mathrm{a}$ & $18.99 \mathrm{a}$ & $11.03 \mathrm{a}$ & $26.05 \mathrm{a}$ \\
4 & $13.94 \mathrm{a}$ & $11.87 \mathrm{a}$ & $15.08 \mathrm{a}$ & $19.55 \mathrm{a}$ & $10.14 \mathrm{a}$ & $29.41 \mathrm{a}$ \\
6 & $17.71 \mathrm{a}$ & $13.54 \mathrm{a}$ & $15.86 \mathrm{a}$ & $17.25 \mathrm{a}$ & $11.69 \mathrm{a}$ & $23.95 \mathrm{a}$ \\
8 & $14.82 \mathrm{a}$ & $13.15 \mathrm{a}$ & $13.09 \mathrm{a}$ & $20.70 \mathrm{a}$ & $10.57 \mathrm{a}$ & $27.66 \mathrm{a}$ \\
10 & $16.86 \mathrm{a}$ & $14.4 \mathrm{a}$ & $13.96 \mathrm{a}$ & $21.97 \mathrm{a}$ & $11.16 \mathrm{a}$ & $21.66 \mathrm{a}$ \\
Control & $17.72 \mathrm{a}$ & $14.28 \mathrm{a}$ & $16.38 \mathrm{a}$ & $17.32 \mathrm{a}$ & $10.27 \mathrm{a}$ & $24.04 \mathrm{a}$ \\
\hline
\end{tabular}

Means in a column followed by the same letter are not significantly different according to DMRT $(P=0.05)$

\section{Discussion}

It is appropriate to manage the density of catnip and Mexican sunflower in jute fields to avert yield loss. The reduction in the morphological features of jute by catnip and Mexican sunflower could be an indication that these weed species compete with jute plants and retard their growth. Similarly, previous studies showed that Mexican sunflower retards the growth of okra and water yam [19, 22]. Also, a previous investigation confirmed that catnip exhibited a phytotoxic effect on garden cress (Lipidium sativum L.) and basil (Ocimum basilicum L.) [23].

The morphological features of jute that were not affected until 8 WAS by the low density of Mexican sunflower imply that it takes a long interaction time for low weed density to manifest growth retardation, unlike high density. Furthermore, the magnitude of change in jute morphology differed for high and low densities of Mexican sunflower, suggesting that the degree of interference resulting from Mexican sunflower is density-dependent. This finding corroborates the assertion that jute plant's morphological features reduce with increasing weed density [7]. The decrease in the leaves, branches, and height of the jute plant, which intensified as catnip density increased, also supports the notation that weed competition increased with weed density.

It can be inferred from this study that weed species influence the growth of jute differently at the same density. For instance, at two (2) weed plants per pot, the number of jute leaves and branches was not reduced by Mexican sunflower, whereas catnip reduced the number of jute leaves and branches. Similarly, Ronchi and Silva [12] found that the effects of competition by Nicandra physalodes (L.) Gaertn. and Sida rhombifolia L. against coffee plants were slight compared to Bidens Pilosa L., Commelina diffusa Burm.f., Leonurus sibiricus L., and Richardia brasiliensis Gomes that markedly reduced the growth of coffee plants. Raoofi and Alebrahim [24] suggested that weeds' morphology may be responsible for this differential impact. Sedge weeds were reported to be more detrimental to jute plants than grass weeds. Though the weeds evaluated in this study are both broadleaved species, their morphological differences can not be ignored. Hence, the action threshold for weed control should factor in weed species.

The stems and branches of jute plant are points of leaf attachment. Hence, the negative impact of catnip and Mexican sunflower interactions on these was probably responsible for the reduced jute leaves. This finding agrees with Law-Ogbomo and Osaigbovo [25] that the plant height and the number of branches of jute have a significant positive correlation with its number of leaves.

The reduction in the height and the number of jute branches could be due to the shading 
effect of catnip and Mexican sunflower on the jute plant. Similarly, Silverio [26] found that jute plants exposed to sunlight were taller than those in the shade. The leaves, stems, and branches of the jute plant are chlorophyllous. These jute parts contribute to the synthesis of photosynthate and the subsequent accumulation [27]. Therefore, the decline in the number of leaves, length of stems, and branches of the jute plant may be responsible for the reduced weight.

The dry weights of jute plants, which decreased due to catnip and Mexican sunflower interactions, justify the need to circumvent these weeds from reaching a detrimental density of 100 plants per square meter during jute production. However, the comparable fresh weights of jute plants in weedy and weed-free pots suggest that the use of plant fresh weight to evaluate weed competition is not reliable, more so that the dry weight reflects otherwise. Similarly, Huang et al. [28] reported that plant fresh weights are inappropriate growth indicators, giving different growth indications from the dry matter of some plants.

The change in the nutrient composition of jute by Mexican sunflower interaction, unlike catnip, suggests that weed species impact differently on nutrient composition of crops. Previous studies [29, 30] identified that weed management, such as hoe weeding, mulching, and herbicide application influences the nutrient composition of fluted pumpkin (Telfairia occidentalis Hook.f.) and maize (Zea mays L.). It also alters the composition of weed population [31]. Hence, this study suggests that the ability of weed management to impact the nutrient composition of crops may emanate from its modifying role on the predominance of weed species. In addition, alteration of physiological processes, such as nutrient uptake, photosynthesis, respiration, and transpiration, influences plants' proximate composition [32]. Hence, the proximate composition of the jute that was not affected by the catnip interaction of 100 500 catnip plants per square meter suggests that these catnip densities did not significantly enable physiological conditions that bring about changes in jute's nutrient composition.

The decrease in the protein content of jute interacting with Mexican sunflower plants in this study agrees with the reported reduction in the protein content of alfalfa (Medicago sativa L.) growing in weedy environments [23]. The lowered protein content of jute may have resulted from reduced nitrogen uptake from the soil. Earlier studies showed that the protein content of plants increases with increasing soil nitrogen [33, 34]. The reduced nitrogen uptake may be due to the competition caused by 6 Mexican sunflower plants per pot. The inability of Mexican sunflower plant densities of 8 and 10 plants per pot to reduce the protein content of jute suggests that intraspecific competition at this level had a mitigating effect on its interspecific competition.

The increase in the carbohydrate content of jute occurred concurrently with a decrease in its protein content. Similarly, Belle et al. [35] reported the same finding with the carbohydrate and protein contents of marandú palisade grass (Brachiaria brizantha (A.Rich.) Stapf) exposed to weeds. Hence, this study establishes an inverse relationship between the jute's carbohydrate content and its protein content.

\section{Conclusions}

Catnip and Mexican sunflower of 100-500 plant per meter square interacting with jute mallow cause a reduction in its morphology. Generally, the degree of reduction caused by 100 and 200 weed plants per square meter was less than that of 500 weed plants per square meter. Weed species such as Mexican sunflower alters the nutritional quality of jute. Hence, the catnip and Mexican sunflower density interacting with jute mallow should be managed below 100 plants per square meter to prevent yield loss.

\section{References}

1. Raifu, I., \& Soyelu, 0. (2017). Physicochemical basis for relative susceptibility of two jute mallow morphotypes to Acraea eponina Cramer. Ife Journal of Agriculture, 28(1), 96-105.

2. Obeng, E., Kpodo, F. M., Tettey, C. 0., Essuman, E. K., \& Adzinyo, 0. A. (2020). Antioxidant, total phenols and proximate constituents of four tropical leafy vegetables. Scientific African, 7, e00227.

3. Tareq, Z., Bashar, K. K., Amin, R., Sarker, M. D. H., Moniruzzaman, M., Sarker, M. S. A., \& Islam, S. (2020). Nutritional composition of some jute genotypes as vegetables. International Journal of Vegetable Science, 26(5), 506-515.

4. Adediran, 0. A., Ibrahim, H., Tolorunse, K. D., \& Gana, U. I. (2015). Growth, yield and quality of jute mallow (Corchorus olitorius L.) as affected by different nutrient sources. International Journal of Agriculture Innovations and Research, 3(5), 2319-1473.

5. Tyokumbur, E. T., \& Okorie, T. (2011). Bioconcentration of trace metals in the tissues of two leafy vegetables widely consumed in South West Nigeria. Biological Trace Element Research, 140(2), 215-224.

6. Karki, S., Timsina, G. P., \& Sharma, S. (2021). Performance studies on jute genotypes (Corchorus olitorius L.) for screening fibre yield components and biotic stress factors under terai region of Province-1 Nepal. Journal of Current Opinion in Crop Science, 2(1), 130-133.

7. Aladesanwa, R., \& Ayodele, 0. (2011). Weed Control in the LongFruited Jute (Corchorus olitorius L.) with Paraquat alone and in combination with Glyphosate at varying doses including their effects on its growth, development, yield and nutrition. $A p$ plied Tropical Agriculture, 15(1-2), 65-75.

8. Datta, M. K., Halder, P., Biswas, U., \& Kundu, C. K. (2017). Effect of different weed management practices on growth and yield 
of tossa jute (Corchorus olitorius) in the new alluvial zone of West Bengal, India. International Journal of Current Microbiology and Applied Sciences, 6(11), 1118-1123.

9. Ferdous, J., Hossain, M. S., Alim, M. A., \& Islam, M. M. (2020). Effect of weeding and herbicide management on fibre yield and yield attributes of tossa jute. Bangladesh Agronomy Journal, 23(1), 101-106.

10. Hossain, M. S., Ferdous, J., Kamrujjaman, M., Alim, M. A., \& Islam, M. M. (2020). Fibre yield, yield attributes and economics of tossa jute (Corchorus olitorius L.) as affected by different weedicides. International Journal of Sustainable Agricultural Technology, 16(5), 14-19.

11. Storkey, J., \& Neve, P. (2018). What good is weed diversity? Weed Research, 58(4), 239-243.

12. Ronchi, C. P., \& Silva, A. A. (2006). Effects of weed species competition on the growth of young coffee plants. Planta Daninha, 24(3), 415-423.

13. Jama, B., Palm, C. A., Buresh, R. J., Niang, A., Gachengo, C., Nziguheba, G., \& Amadalo, B. (2000). Tithonia diversifolia as a green manure for soil fertility improvement in western Kenya: a review. Agroforestry Systems, 49(2), 201-221.

14. Mutlu, S., Atici, Ö., Esim, N., \& Mete, E. (2011). Essential oils of catmint (Nepeta meyeri Benth.) induce oxidative stress in early seedlings of various weed species. Acta Physiologiae Plantarum, 33(3), 943-951.

15. Akbar, S. (2020). Nepeta cataria L. (Lamiaceae). In Handbook of 200 Medicinal Plants (pp. 1279-1285). Cham: Springer.

16. Dmitrović, S., Perišić, M., Stojić, A., Živković, S., Boljević, J., Živković, J. N., Aničić, N., Ristić, M., \& Mišić, D. (2015). Essential oils of two Nepeta species inhibit growth and induce oxidative stress in ragweed (Ambrosia artemisiifolia L.) shoots in vitro. Acta Physiologiae Plantarum, 37(3), 64.

17. Amulu, L., Oyedele, D., \& Adekunle, 0. (2021). Effects of Sunn hemp (Crotalaria juncea) and Mexican sunflower (Tithonia diversifolia) soil amendments on yields and quality of two indigenous vegetables grown in a nematode-infested field. Indian Phytopathology. doi: 10.1007/s42360-021-00341-3

18. Bozok, F., Cenet, M., Sezer, G., \& Ulukanli, Z. (2017). Essential oil and bioherbicidal potential of the aerial parts of Nepeta nuda subsp. albiflora (Lamiaceae). Journal of Essential Oil-Bearing Plants, 20(1), 148-154.

19. Olabode, 0. S., Ogunsola, A., Oladapo, 0. S., \& Sangodele, A. 0. (2019). Effectiveness of alternative control methods for Tithonia diversifolia on water yam (Dioscorea alata) plot. Asian Journal of Research in Crop Science, 3(3), 1-6.

20. AOAC. (2012). Official Methods of Analysis of AOAC International (Vols I \& II). (19th ed.). Gaithersburg, MD: AOAC International.

21. George D., \& Mallery P. (2016). IBM SPSS Statistics 23 Step by Step: A Simple Guide and Reference. (14th ed.). New York, NY: Routledge.

22. Olabode, 0. S., Adesina, G. 0., \& Ajibola, A. T. (2010). Seasonal effects on the critical period for weed removal and okra performance on Tithonia diversifolia (Helmsl) A.Gray infested field. Academic Journal of Plant Sciences, 3(4), 156-160.
23. Saharkhiz, M. J., Zadnour, P., \& Kakouei, F. (2016). Essential oil analysis and phytotoxic activity of catnip (Nepeta cataria L.). American Journal of Essential Oils and Natural Products, 4(1), 40-45.

24. Raoofi, M., \& Alebrahim, M. T. (2017). A comparison of weeds interference and non-interference at different planting densities, on yield, nutritional value and some morphological traits of alfalfa (Medicago sativa L.). Sarhad Journal of Agriculture, $33(2), 220-231$.

25. Law-Ogbomo, K. E., \& Osaigbovo, A. U. (2018). Growth and yield performance of jute mallow (Corchorus olitorius L.) In response to nitrogen levels of poultry manure in an 'ultisols' environment. Journal of Organic Agriculture and Environment, $5(2), 5-12$.

26. Silverio, F. D. (2015). Morpho-Anatomical Structure and DNA Extract of Sun and Shade Leaves of Jute (Corchorus capsularis L.). American Journal of Agriculture and Forestry, 3(6-1), 1-5.

27. Aschan, G., \& Pfanz, H. (2003). Non-foliar photosynthesis - a strategy of additional carbon acquisition. Flora-Morphology, Distribution, Functional Ecology of Plants, 198(2), 81-97.

28. Huang, P., de-Bashan, L., Crocker, T., Kloepper, J. W., \& Bashan, Y. (2017). Evidence that fresh weight measurement is imprecise for reporting the effect of plant growth-promoting (rhizo) bacteria on growth promotion of crop plants. Biology and Fertility, 53(2), 199-208.

29. Osadebe, V. 0., Echezona, B. C., \& Bakare, S. 0. (2014). Effect of weed management and cutting frequency on the leaf yield and proximate composition of fluted pumpkin (Telfairia occidentalis Hook F.). American-Eurasian Journal of Agricultural \& Environmental Sciences, 14(7), 664-673.

30. Omovbude, S., Oroka, F.0., \& Udensi, E. U. (2017). Effect of Different Weed Control Practices on Proximate Composition, Nutrient Concentration and Uptake of Maize (Zea mays L.). IOSR Journal of Agriculture and Veterinary Science, 10(2), 98-104.

31. Rana, S. S., Sharma, R., Singh, A., \& Kumar, S. (2019). Studies on shifts in weed flora in maize (Zea mays L.) in Kangra district of Himachal Pradesh. Journal of Research in Weed Science, 2(3), 230-240.

32. Khan, I., Azam, A., \& Mahmood, A. (2013). The impact of enhanced atmospheric carbon dioxide on yield, proximate composition, elemental concentration, fatty acid and vitamin $C$ contents of tomato (Lycopersicon esculentum). Environmental Monitoring and Assessment, 185(1), 205-214.

33. Shang, C., Chen, A., Chen, G., Li, H., Guan, S., \& He, J. (2017). Microbial biofertilizer decreases nicotine content by improving soil nitrogen supply. Applied Biochemistry and Biotechnology, 181(1), 1-14.

34. Yadav, S., Kumar, R., Chauhan, S. S., Kumar, R., \& Kumar, M. (2020). Effect of Different Nitrogen Levels and Varieties on Protein and Nitrogen Content in Grain and Nitrogen Uptake by Barley (Hordeum vulgare L.) in Sodic Soil. International Journal of Current Microbiology and Applied Sciences, 9(2), 612-618.

35. Belle, J., Marchi, S., Martins, D., Sousa, A., \& Pinheiro, G. (2018). Nutritional Value of Marandú Palisade Grass According to Increasing Coexistence Periods with Weeds. Planta Daninha, 36, e018170348.

Ayodele 0. P. ${ }^{1}$, Aluko 0. A. ${ }^{2}$, Adegbaju 0. D. ${ }^{3}$ Вплив щільності котячої м'яти справжньої (Nepeta cataria L.) і мексиканського соняшнику (Tithonia diversifolia L.) на ріст, урожайність та вміст деяких сполук у рослинах джуту довгоплідного (Corchorus olitorius L.). Plant Varieties Studying and Protection. 2021. Т. 17, № 2. C. 155-163. https://doi.org/10.21498/2518-1017.17.2.2021.236523

${ }^{1}$ Department of Agronomy, Adekunle Ajasin University Akungba-Akoko, Ondo State, Nigeria, e-mail: olatunde.ayodele@aaua.edu.ng 2Institute of Agricultural Research and Training, Obafemi Awolowo University, Moor Plantation, P. M. B 5029, Ibadan, Nigeria, e-mail: bunmialuko2010@gmail.com

${ }^{3}$ Medicinal Plants and Economic Development (MPED) Research Centre, Department of Botany, University of Fort Hare, Alice 5700, South Africa, e-mail: funmaj2005@gmail.com

Мета. Джут довгоплідний (Corchorus olitorius L) - це овочева й луб'яна культура, яку вирощують у тропіках. Поширеними бур'янами, що засмічують його посіви, є котяча м'ята справжня (Nepeta cataria L.) і мексиканський соняшник (Tithonia diversifolia L). У нашому дослідженні вивчали ріст, урожайність і склад деяких компонентів у рослинах 
джуту довгоплідного за умови присутності котячої м'яти справжньої і мексиканського соняшнику та в середовищі, вільному від бур'янів. Методи. Дослідження включало два скринінгових експерименти за повністю рендомізованою схемою в шести повтореннях. Схема досліду в експериментах була такою: 0 (контроль), 2, 4, 6, 8 і 10 бур'янів на ємність для вирощування. 3 урахуванням площі поверхні використаних ємностей, така кількість відповідала 0, 100, 200, 300, 400 і 500 бур'янам на 1 м². Параметри росту джуту довгоплідного реєстрували щотижня 35 до 8 тижня після сівби, а врожай збирали через 8 тижнів. Уміст деяких сполук у рослинах джуту оцінювали з використанням стандартних процедур, викладених Асоціацією офіційних сільськогосподарських хіміків. Отримані результати були оброблені із застосуванням методів дисперсійного аналізу
(ANOVA). Результати. Котяча м'ята справжня й мексиканський соняшник за щільності від 100 рослин на квадратний метр набільш негативно впливали на морфологічні характеристики джуту довгоплідного. Ці бур'яни, за щільності 100-500 рослин на квадратний метр, зумовлювали також зменшення сухої ваги джуту довгоплідного. За певних умов, мексиканський соняшник може також спричиняти зменшення вмісту сирого протеїну в джуті довгоплідному. Висновки. Для запобігання втрат урожаю рекомендується підтримувати чисельність рослин котячої м'яти справжньої та мексиканського соняшнику в посівах джуту довгоплідного меншою ніж 100 шт./м².

Ключові слова: Corchorus olitorius; мексиканський соняшник; котяча м'ята справжня; густота бур'янів; уміст сполук.

Надійшла / Received 04.05.2021

Погоджено до друку / Accepted 09.06.2021 